INDIAN INSTITUTE OF MANAGEMENT AHMEDABAD

\title{
IIMA
}

Working Paper

The Role of Insolvency Tests: Implications for Indian Insolvency Law

M. P. Ram Mohan

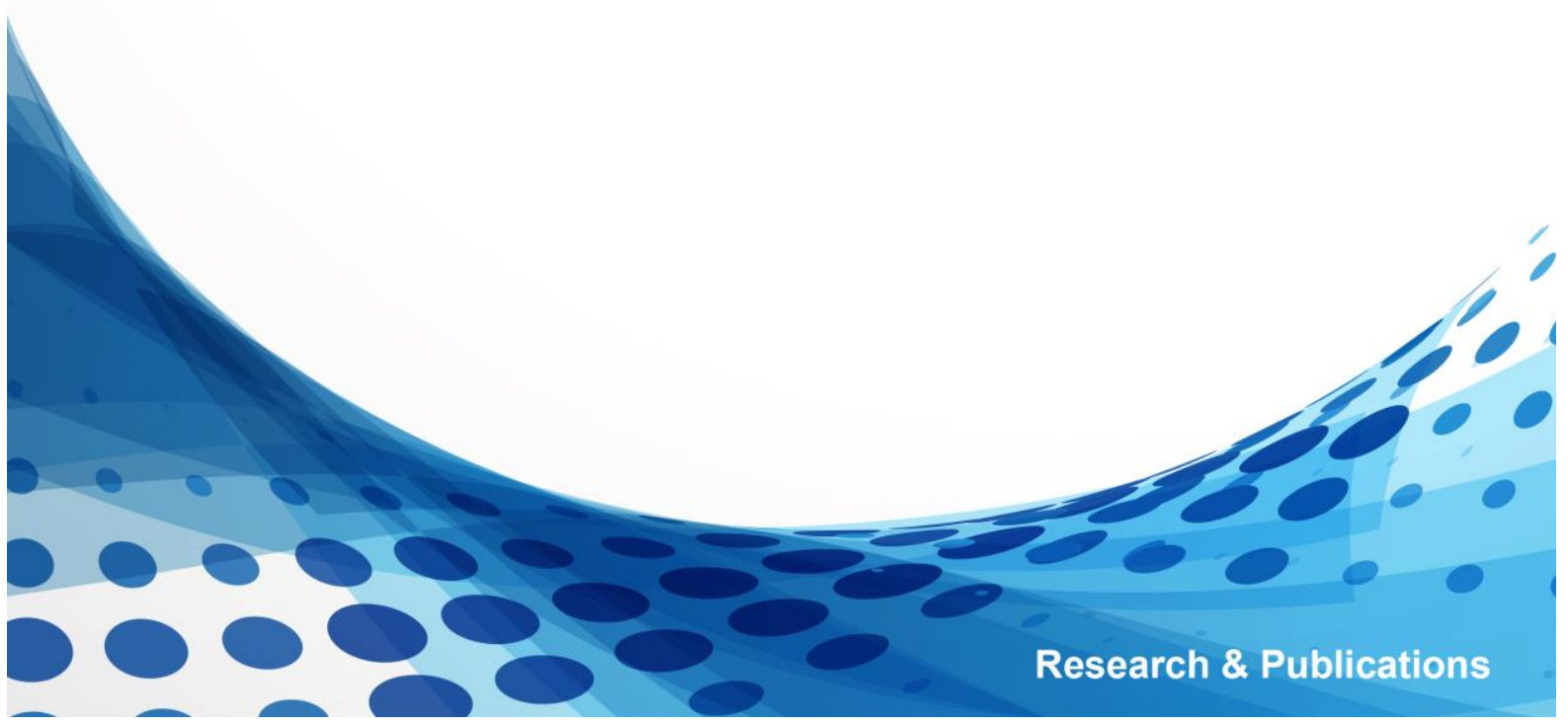




\title{
The Role of Insolvency Tests: Implications for Indian Insolvency Law
}

\author{
M. P. Ram Mohan
}

\section{April 2021}

The main objective of the working paper series of the IIMA is to help faculty members, research staff and doctoral students to speedily share their research findings with professional colleagues and test their research findings at the pre-publication stage. IIMA is committed to maintain academic freedom. The opinion(s), view(s) and conclusion(s) expressed in the working paper are those of the authors and not that of IIMA. 


\title{
The Role of Insolvency Tests: Implications for Indian Insolvency Law
}

\begin{abstract}
:
Insolvency determination is central to the formal insolvency and bankruptcy proceedings of a debtor entity. In determining whether a company is solvent or insolvent, two tests are generally used by the bankruptcy courts across all jurisdictions: the Commercial Cash Flow and the Balance Sheet test. While enacting IBC, India has moved away from the traditional dual test approach followed by Indian courts under the Indian Companies Act to specific Cash Flow test. This paper discusses conceptual basis of the two tests as evolved under insolvency laws of the United Kingdom and United States, with a view to comparatively study the nascent Indian insolvency regime. We conclude that irrespective of the statutorily prescribed test, over the years, courts across jurisdictions have taken recourse to both the tests to ascertain the overall commercial viability. In this lies an answer for India's work in progress - Insolvency \& Bankruptcy Code, 2016. While the cash flow test is the test specified under Indian insolvency law, the paper shows, both the tests exist for a reason and Indian regime may have to adopt international experience in applying both the tests more or less jointly within the spirit of efficient debt resolution.
\end{abstract}

Keywords: Cash Flow Test; Balance Sheet Test; Insolvency \& Bankruptcy Code, 2016; India

JEL codes: K21, K10, K2, F23

\footnotetext{
*Associate Professor, Strategy Area, Indian Institute of Management Ahmedabad. I am grateful to Urmil Shah for his research assistance. Many thanks to J B Heaton, Praachi Misra and Vishakha Raj for review comments. Please share your comments: <mprmohan@iima.ac.in>
} 


\section{Introduction:}

The Insolvency and Bankruptcy Code (IBC) of India enacted in 2016, consolidates and amends the laws concerning reorganization and insolvency resolution. The aim is to, "to reduce the uncertainty that arises from the application of multiple laws administered by different authorities, and the consequent delay and reduction in value". ${ }^{1}$ With this enactment, the provisions of winding-up and liquidation were repealed from the Companies Act, 2013 (CA, 2013). The IBC thus proposed a paradigm shift, by seeking to encourage insolvency resolution as a mode of debt recovery, and the winding up of the debtor as a measure of last resort ${ }^{2}$. This is unlike the previous CA 2013 regime, where companies were wound up for their inability to pay debts. Accordingly, under the IBC, the solvency determination test has also undergone changes. The solvency analysis is the foundational measure to ascertain beginning of formal insolvency proceedings, and is essential to ensure that this route is not taken on account of frivolous threats from the creditors ${ }^{3}$. In other words- application of the appropriate test for determining insolvency.

In practice, the determination of insolvency takes into consideration numerous factors including financial statements, adequacy of capital, amount of existing debt etc. and this exercise is complex. ${ }^{4}$ A review of international literature conveys the existence of three insolvency tests - cash flow (or commercial insolvency), balance sheet and the capital adequacy test; with the last utilized very rarely in practice. A company is considered Cash Flow insolvent if it is unable to pay its debts "as they fall due". Along with inability to pay, the failure to pay the debt upon service of demand notice by the creditor within the specified time period is also an application of cash flow insolvency. When the company's reported assets as per the financial statements are less than the reported liabilities, accounting for both contingent and

\footnotetext{
${ }^{1}$ Shreya Prakash, Understanding the Insolvency and Bankruptcy Code, 2016 Analysing Developments in Jurisprudence, Vidhi Centre for Legal Policy (2019), available at: https://www.ibbi.gov.in/webadmin/pdf/whatsnew/2019/Jun/190609_UnderstandingtheIBC_Final_2019-0609\%2018:20:22.pdf

${ }^{2}$ Mukulita Vijayawargiya, Insolvency and Bankruptcy Code: A Miscellany of Perspectives, Insolvency \& Bankruptcy Board of India (2019), available at https://www.ibbi.gov.in/uploads/publication/2019-10-11191135-wv5q0-2456194a119394217a926e595b537437.pdf

${ }^{3}$ Richard S Bradstreet, Should Creditors Rely on the Solvency and Liquidity Threshold for Protection?, 59 Journal of African Law 1 (2015).

${ }^{4}$ Richard M. Cieri, Lyle G. Ganske \& Heather Lennox, Breaking Up Is Hard To Do: Avoiding the SolvencyRelated Pitfalls In Spinoff Transactions, 54 The Business Lawyer 533 (1999)
} 
prospective liabilities, then it is considered Balance Sheet insolvent. ${ }^{5}$ The capital adequacy test determines if the company has sufficient internal capital to manage operational expenses; and the test isn't utilized independently but in conjugation with either of two tests. ${ }^{6}$ Since this test is not popularly utilized in practice and has no application in India as of now, elaborating on it falls outside the scope of this paper.

The Bankruptcy Law Reforms Committee (BLRC) ${ }^{7}$ setup by the Government of India to draft a new bankruptcy law suggested in its interim report that 'balance sheet insolvency' and 'cash flow insolvency' should be recognized as separate grounds to avoid any conflicts with the statutory demand test. The Report stated that to prevent the misuse of provisions by recalcitrant solvent debtors by abusing the process of law, there is a need to incorporate both the cash flow and balance sheet test. In other words, "if a company fails to pay an undisputed debt of prescribed value, the creditor should be entitled to a winding up order irrespective of whether it is insolvent (in commercial or balance sheet terms) or not."8 However, these recommendations by the BLRC were not reflected in its final report nor in the enacted IBC.

While there can be no straightforward mechanical application of any one test in insolation to the others in identifying insolvency of a debtor corporation; evidences shows that all matured jurisdictions take resort to both the tests to ascertain the overall commercial reality. ${ }^{9}$ Further, the scope of insolvency determination also extends beyond mere ascertainment of insolvency, including transactions which are avoidable in nature ${ }^{10}$ i.e. which are either preferential, fraudulent, or undervalued transaction. For example, an objective determination of insolvency helps in imputing liability upon the recalcitrant directors of the debtor for the loss of corporate property outside the ordinary course of business. ${ }^{11}$

This paper provides an analysis of the existing theoretical framework and judicial practice, which has evolved internationally with respect to Commercial Cash Flow and the Balance

\footnotetext{
${ }^{5}$ Kubi Udofia, Establishing Corporate Insolvency: The Balance Sheet Insolvency Test, Harvard Law School Bankruptcy Roundtable (2019).

${ }^{6}$ J.B. Heaton, Solvency Tests, 63 The Business Lawyer 3(2007).

${ }^{7}$ Interim Report of the Bankruptcy Law Reforms Committee, Pg. No. 25 (2015).

${ }^{8}$ The BLRC Interim Report was quoted by the Supreme Court in Mobilox Innovations Private Ltd v. Kirusa Software Private Ltd., AIR 2017 SC 4532, albeit without any further elaboration the insolvency tests.

${ }^{9}$ Since, both the insolvency tests take into consideration different variables, it is possible that in a given context, a company maybe cash flow insolvent whereas balance sheet solvent. See. Howship Holdings Pty Ltd v Leslie (1996) 14 ACLC 1.

${ }^{10}$ Gerard McCormack, Universalism in Insolvency Proceedings and the Common Law, 32 Oxford Journal of Legal Studies 2 (2012)

${ }^{11}$ NACEPF v. Gheewala, 930 A.2d 92. See also, Kristin van Zwieten, Related Party Transactions in Insolvency, European Corporate Governance Institute Working Paper No. 401/2018.
} 
Sheet tests, and assess their development in the Indian corporate insolvency framework vis-àvis other matured insolvency jurisdictions. The paper is organised as follows: Section 2 details conceptual synopsis of the application of the cash flow and balance sheet insolvency tests; Section 3 covers the pre- IBC regime covering the nature of the tests under the Indian Companies Act (1956 and 2013); Section 4 maps jurisdiction analysis of insolvency tests in the United States and United Kingdom; Section 5 analyses the role of the tests on the issues of fiduciary duties and avoidable transactions, and finally Section 6 concludes with the Indian insolvency regime and way forward towards consideration and application of both the tests within the spirit of efficient debt resolution.

\section{Conceptual basis of the cash flow and balance sheet solvency tests}

Historically, the roots of cash flow test lie in the equity jurisprudence derived from civil law, while balance sheet test was always been embodied in common law with the earliest statutory recognition of the latter being the US Bankruptcy Code, 1978 (UBC). ${ }^{12}$ The distinction between the cash flow and balance sheet tests stems from the fact that in commercial restructuring of the debtor, the immediate concern of the creditor is recovery of his debts on or before the maturity date. ${ }^{13}$ Thus, a cash flow insolvency is easier to be established ${ }^{14}$, perhaps even during instances of one-off default by the debtor ${ }^{15}$. Contrastingly, balance sheet test doesn't concern itself with the temporary lack of liquidity viz-a-viz the cash flow test and relies upon contingent liabilities and future cash flows. The determination under the balance sheet test, is based on the accounting principles, and accounting standards adopted by different jurisdictions. ${ }^{16}$

The situation of being cash flow insolvent and balance sheet solvent can be explained as "the company may at the same point of time be wealthy and insolvent". To illustrate, a real estate company which has assets worth INR 200,000 in form of land properties and liabilities worth INR 100,000 as on 01.05 .2020 . While the debt of INR 100,000 is matured on the same date

\footnotetext{
12 J Honsberger, The Failure to Pay One's Debts Generally As They Become Due, 54 American Bankruptcy Law Journal 153 (980).

${ }_{13}$ Arturo Bris, Ivo Welch, Ning Zhu, The Costs of Bankruptcy: Chapter 7 Liquidation versus Chapter 11 Reorganization, The Journal of Finance (2006).

${ }^{14}$ D. Baird, Loss Distribution, Forum Shopping, and Bankruptcy: A Reply to Warren, 54 University of Chicago Law Review 815 (1987).

${ }^{15}$ Re Globe New Patent Iron \& Steel Co, (1875) LR 20 Eq 337.

${ }^{16}$ It must however be noted that the generally accepted accounting principles and accounting standards record asset values based upon historical costs and during the determination of balance sheet insolvency, the proper market value of the assets of the debtor will be taken into consideration. See. DeRosa v. Buildex Inc. (in re F \& $\mathrm{S}$ Cent. Mfg. Corp.), 53 B.R. 842, 849 (Bankr. E.D.N.Y. 1985). Jonathan Rickford, Legal Approaches to Restricting Distributions to Shareholders: Balance Sheet Tests and Solvency Tests, 7 European Business Organization Law Review (2006).
} 
and it doesn't have the required cash flows to repay, the company will be considered as cash flow insolvent. However, the significant point is that the company still has locked up and presently unrealisable assets more than the present debt and accordingly may be considered balance sheet solvent. Thus the insolvency diagnosis often depends upon the test that is applied as insolvency under one of the test may amount to solvency under the other and vice versa. ${ }^{17}$ The cash flow test is a test of liquidity, however, the balance sheet test is implemented when financial facts or data is available. ${ }^{18}$ A possible combination of the cash flow and balance sheet can be found in winding-up legislation of numerous jurisdictions where the Courts have to take into consideration "contingent and prospective liabilities and assets" while determining inability to pay debt as per maturity date. ${ }^{19}$ As it will be shown in this paper, the distinction has posed problems for the judiciary in making uniform interpretations across jurisdictions resulting in judicial inconsistency.

\subsection{Cash Flow Insolvency}

At the outset it is essential to understand that the formation and application of the cash flow test varies under different legislations. Thus, the cash flow test can be sub-divided into the statutory demand test, where upon failure of payment of the demand served notice by the creditor, the debtor can be declared insolvent and judgment debtor test, where a decree or judgment order has been passed in favour of the creditor to execute the debt. For all practical purposes, the bankruptcy regime exists primarily to solve the common pool problem of liquidation estate becoming inadequate to satisfy claims of the creditors. ${ }^{20}$ The benefits of cash flow insolvency lies in the fact that it creates a legally certain determination of insolvency for recalcitrant debtors. The underlying foundation of any insolvency statute should not be to utilize the balance sheet test as legal defence for the debtors towards winding up, when prima facie the debtor is cash flow insolvent. ${ }^{21}$

Under the cash flow test, the date of maturity of the debt is considered an adequate cause of action to file suit for winding up. ${ }^{22}$ The test relies on the premise that a temporary lack of

\footnotetext{
${ }^{17}$ Parkway/Lamar Partners, L.P. v. Tom Thumb Stores, Inc., 877 S.W.2d 848 (Tex. App. 1994).

18 The financial data will include predictions on contingent liabilities and future cash flows. See. B. Jones, Insolvency and the Balance Sheet, 9 Insolvency Law \& Practice 5 (1993).

${ }^{19}$ JF Corkery, Winding up by the Court for Inability to Pay Debts: The Court's Exercise of Its Discretion, 8 Adelaide Law Review. 61 (1982-1983).

20 Thomas H. Jackson, The Logic and Limits of Bankruptcy Law, Harvard University Press, Cambridge (1986).

${ }^{21}$ Meng Seng Wee, Understanding Commercial Insolvency and Its Justifications as a Test for Winding Up, 62 Lloyd's Maritime and Commercial Law Quarterly 84 (2015).

22 J.B. Heaton, Simple Insolvency Detection for Publicly Traded Firms, Harvard Law School Bankruptcy Roundtable (2019).
} 
liquidity is often a symptom of larger problems affecting the debtor company and early resolution of debts can in fact aid the debtor company to identify and resolve any deep-rooted problems with the management and operations. ${ }^{23}$ The application of cash flow insolvency extends beyond determination of solvency, to ascertain if the debtor company has carried on its business operations to defraud creditors by providing preferential treatment to certain category of creditors. ${ }^{24}$ The date of maturity becomes the relevant date for calculation of the look-back period to ascertain such suspicious transactions and helping the directors of the debtor company to ascertain the twilight period, post which their fiduciary duties towards creditors begin of preserving the liquidation estate. ${ }^{25}$

\subsection{Balance Sheet Insolvency}

The balance sheet insolvency test doesn't consider courts as mere forum of debt recovery but also for resolution of the business of the debtor company. The US Bankruptcy Code provides for a comparison of the asset side and liability side of the balance sheet to ascertain insolvency of the debtor corporation, thus legislatively incorporating the balance sheet test ${ }^{26}$. For purposes of the valuation of the debtor corporation and determination of fraudulent preferences, reference is made to the maturity date under the US Code. ${ }^{27}$ The balance sheet test is argued as a practical application of commercial business practices where it is common for creditors to extend the period of credit based on the friendly business relationships between the parties. ${ }^{28}$ The reliability upon balances of assets and liability in the balance sheet test forming part of financial statements, evidences the transparent nature of the test. ${ }^{29}$

A mechanical application of the cash flow test, without reference to the future contingent and prospective liabilities can result in closing down of start-up companies even before they are provided with a level playing field to compete with the market leaders. Similarly, banks may not necessarily have ready cash flow with itself on a particular day to pay-off the significant

\footnotetext{
${ }^{23}$ Akshaya Kamalnath, Corporate Insolvency Resolution Law in India - A Proposal to Overcome the 'Initiation Problem', 88 University of Missouri-Kansas City Law Review 631 (2019-2020).

${ }^{24}$ NACEPF v. Gheewalla, 930 A.2d 92; Andrew Keay, The Insolvency Factor in the Avoidance of Antecedent Transactions in Corporate Liquidations, 21 Monash University Law Review 305 (1995).

${ }^{25}$ Geyer v. Ingersoll Publications Co., 621 A.2d 784 (Del. Ch. 1992); Jewel Recovery, L.P. v. Gordon (In Re Zale Corp.), 196 B.R. 348, 354-55 (Bankr. N.D.Tex. 1996).

${ }^{26}$ Corey R. Weber, Proving or Contesting Debtor Insolvency Under the Balance Sheet Test Analyzing Insolvency in Preference and Fraudulent Transfer Litigation, Latham \& Watkins (2012).

${ }^{27} \S 101(32)$ of the US Bankruptcy Code.

28 Taylors Industrial Flooring Ltd v M \& H Plant Hire (Manchester) Ltd., [1990] BCLC 216, 221.

${ }^{29}$ Loftus \& Miller, Solvency Assessment and Financial Reporting, 20 Accounting Forum 2 (1996).
} 
number of depositors and such a situation is not characteristic of insolvency. ${ }^{30}$ Similarly, an instance of abuse of dominance of its market position by the dominant enterprise through winding up threats can result in establishment of monopoly in the market by the dominant enterprise. $^{31}$

The essence of balance sheet test lies in the fact that it takes into consideration externalities on account of which the default of payment has occurred. To illustrate, an Indian export-import company relying upon imports of Chinese textiles for sale in the Indian market may be hampered when an embargo on trade is imposed between the countries, resulting in significant business losses. However, such a force majeure situation has arisen not on account of any imprudent business decision by the Indian company; but due to unfavourable trade relations between the countries. Any threat of winding up for default in payment of debts due to a single force majeure event can result in closing down of a growing business without any fault on part of its management. While the cash flow test has been a popular choice in many jurisdictions, the test is also contested. It is argued that the cash flow solvency test acts as a detriment towards the effective growth and sustainability of the debtor company as the threats issued through an application for winding up can result in loss of goodwill and downward trends towards the share price. ${ }^{32}$

\section{Insolvency tests under Indian legal regime}

As discussed earlier, the IBC represents sea change to resolving insolvency from the earlier regime, and this section gives an overview of the interpretation and application of the insolvency tests. Section 434 of the CA 1956 defines "inability to pay" - clause (1) incorporated the statutory demand test; clause (2) provided for judgment debtor test; and clause (3), of the mixed provision of balance sheet and commercial cash flow test. With the need to update the legislation governing company registration and winding-up to improve doing business and corporate governance by making the company management more accountable and transparent CA 2013 was introduced. Section 271(2) of the CA 2013 covers the exact legislative language and by that virtue the same test as under the former legislation.

\footnotetext{
${ }^{30}$ Philipp Bagus \& David Howden, Central Bank Insolvency: Causes, Effects and Remedies, 39 Journal of Social, Political and Economic Studies 23 (2014).

${ }^{31}$ Horst Eidenmüller, The Rise and Fall of Regulatory Competition in Corporate Insolvency Law in the European Union, 20 European Business Organization Law Review 547 (2019).

${ }^{32}$ George M. Treister \& J. Ronald Trost, Fundamentals of Bankruptcy Law, 44 The Business Lawyer 4 (1989); Sandell v Porter (1966) 115 CLR 666; Expo International v. Chant, [1979] 2 NSWLR 820.
} 
The Interim Report by the Bankruptcy Law Reforms Committee provided a background to judicial precedents under the CA 1956 and 2013 relating to "inability to pay debts". As discussed in the introduction, though the committee in its report discussed both cash flow and balance sheet tests by Indian courts, however, when the IBC was enacted, the Parliament retained only the Cash Flow test. In this section we elaborate on the reasons why and how Indian courts choose, many times confusingly, to apply different tests under the earlier regime. The literature review suggests that there was a hesitation giving due recognition and understanding of the two tests by the Courts ${ }^{33}$, however it would be wrong to state that the Indian Courts didn't deal with both aspects of commercial insolvency.

One of the earlier interpretations on the tests was in Hyderabad Vegetable Products ${ }^{34}$ case where the Andhra Pradesh HC clarified that inability to pay debts meant commercial insolvency, and it was meant to include only cash flow test. Similarly, In Advent Corporation, the Bombay HC held that the Court has no discretion in not winding up companies when an undisputed debt is proved, ${ }^{35}$ that once the debt is proved that the company is unable to pay debt, it will be wounded compulsorily. The same Court decades later in M. Suryanarayana Case analysed the cash flow part of the inability to pay test as "the company's ability to meet its liabilities as and when they arise" ${ }^{36}$, thereby suggesting a preference for cash flow approach as against the mixed provision. The lack of broader application of the term "contingent and prospective liabilities" under section 434 CA, 1956 by Courts can be understood from the judgment of the Kerala HC. Kerala HC in New Era Manufacturing "it is true that ordinarily the court does not go behind the company's balance-sheet to ascertain its financial position, but this does not mean that the mere fact that a particular item appears in the balance-sheet under the head 'Liabilities' conclusively establishes that that item is a liability of the company in the sense in which the word 'liability' is used and referred to therein must be a debt which the company has, or might or will have to pay, something which cannot be said with regard to

\footnotetext{
${ }^{33}$ Aparna Ravi, Indian Insolvency Regime in Practice: An Analysis of Insolvency and Debt Recovery Proceedings, 50 Economic and Political Weekly 51 (2015).

${ }^{34}$ State of Andhra Pradesh v. Hyderabad Vegetable Products Co. Ltd., Hyderabad, [1962] 32 CompCas 64 (Andhra Pradesh).

${ }^{35}$ Section 434(1)(a) Companies Act, 1956 states that a company shall be deemed to be unable to pay its debts if a creditor, by assignment or otherwise, to whom the company is indebted in a sum exceeding five hundred rupees then due, has served on the company, by causing it to be delivered at its registered office, by registered post or otherwise, a demand under his hand requiring the company to pay the sum so due and the company has for three weeks thereafter neglected to pay the sum, or to secure or compound for it to the reasonable satisfaction of the creditor. In the Matter of Advent Corporation Pvt. Ltd, [1969] 39 CompCas 463 (Bom). Followed in Destinations of the World (Subcontinent) Pvt. Ltd. v. Raj Travels and Tours Ltd., 2013 (7) BomCR 320.

${ }^{36}$ M. Suryanarayana v. Stiles India Limited, Rep. by Its Managing Director, 2002 (2) ALD 185.
} 
its share capital." 37 This implies, that Courts have largely been hesitant in placing sole reliance upon only one aspect of the insolvency tests.

\subsection{Conflicting judicial decisions}

Over the years, various Indian High Courts have interpreted the statutory tests under the CA $1956 \& 2013$ according to specific circumstances and this has led to the confusion and lack of clarity on the application of the tests. In Hegde \& Golay Ltd., the Karnataka HC by placing reliance upon Buckley on Companies Act, ascertained that the CA 1956 envisages two distinct types of test of winding-up, both of which are alternatives of each other. ${ }^{38}$ The Bombay HC in Megabyte Consultancy Services, was confronted with the question to ascertain if the inability to pay debts (cash flow test) and consideration of prospective and contingent liabilities (balance sheet test) under the CA 1956 were independent of each other or were complementary in nature. ${ }^{39}$ Here, the creditors served demand notice for repayment of debt. The Court concluded that the creditors must prove both cash flow and balance sheet insolvency for presenting application of winding up, "it may be true that the petitioners have been able to show that monies were advanced by the petitioners to the company and that the cheques when presented were dishonoured; however, that would be the first requirement and that alone by itself is not sufficient and the second requirement of taking into consideration the contingent and prospective liabilities of the company must also be satisfied." ${ }^{40}$ Further, the non-reliance upon solvency of the company based upon any other criteria except commercial solvency is evident from the judgment of the Bombay HC in Ballarpur Industries, "omission to pay except on account of bona fide dispute is sufficient in law to declare wind the company." ${ }^{41}$ The Karnataka HC in 2019 in Milestone Real Estate Fund when faced with application for injunction against threats of insolvency from creditors upheld its verdict in Hegde \& Golay that either of the two tests under section 434(1)(c) of CA 2013 must be proved, albeit without any reference to Megabyte Consultancy, that creditors must rely upon only one of the available tests under Section $454(1)(c)$ to prove inability of the debtor to pay debts. ${ }^{42}$

\footnotetext{
${ }^{37}$ V.V. Krishna Iyer Sons v. New Era Manufacturing Co. Ltd. [1965] 35 Comp Cas 410 (Ker); Paramjit Lal Badhwar vs. Prem Spinning and Weaving Mills Limited, 198660 CompCas 420 All.

${ }^{38}$ Hegde and Golay Limited v. State Bank Of India, ILR 1987 KAR 2673.

${ }^{39}$ Gujarat State Financial Services Limited v. Megabyte Consultancy Services Pvt. Ltd., 1999 (2) Comp LJ 4 (Bom)

${ }^{40}$ Gujarat State Financial Services Limited v. Megabyte Consultancy Services Pvt. Ltd., 1999 (2) Comp LJ 4 (Bom).

${ }^{41}$ Karpara Project Engineering, Surat v. Ballarpur Industries Ltd, C.P No. 8 of 2006.

${ }^{42}$ Milestone Real Estate Fund v. Prisha Properties India Private Ltd., C.P. No.202/2016.
} 
Regarding the interpretation of the balance sheet test, in Shanumgar Mills, the Court was asked to declare the company insolvent by the creditors under section 433(e) of the CA 1956. In this case, the single bench opposed the argument by the debtor of its assets being greater than its liabilities, "the question whether a company would be able to meet its present demands could not entirely depend upon the circumstances that the assets if realised might exceed the liabilities. The nature of the assets is such that they should not be realised if the company were to run. They could not, therefore, be taken as presently realisable assets. That being so, they cannot be properly taken into consideration for considering the ability of the company to pay its debts." ${ }^{\prime 3}$ Thus, Courts are inclined not to look at assets of the debtor in isolation. The division bench on appeal agreed with the reasoning of the single bench holding that "the debts of the company could not be paid without selling its machinery and building and, if the machinery and the building were to be sold, the mills could not run and the company would necessarily have to be wound up,"44 thus adhering to the ratio of Advent Corporation that in absence of fulfilment of conditions under section. 434, the company has to be compulsorily wounded up. Another instance where the balance sheet part of Section 434 was relied upon was in Tata Iron \& Steel Co. v. Micro Forge (India) ${ }^{45}$ where the statutory demand notice was served upon the debtor and yet the debtor failed to repay the debt. The Gujarat HC in this case widened the discretion of the court during winding up to the extent of 'commercial death of a company' and in such circumstances be inclined towards rejecting the winding up petition. This shows that over a period of time Courts have started considering factors outside of inability to pay debts without mechanical application of factors under section 434 as done in Advent Corporation.

\subsection{Attempts by the Supreme Court: inconsistency continues}

The Supreme Court in IBA Health v. Info Drive Systems when debtor was faced with demand notice under section 434 of CA, 1956, highlighted the perils of placing reliance solely upon one test, "solvency of a company cannot stand in the way of a winding-up petition if the company does indeed owe an unpaid debt to the creditor; however, commercial solvency can be seen relevant as to whether there was a dispute as to the debt, not as a ground in itself, that

\footnotetext{
The proviso to S.5 of Companies (Transfer of Pending Proceedings) Rules, 2016 provides that cases where opinion has been forwarded by Board of Industrial and Financial Restricting for winding up of a company to a High Court and where no appeal is pending, the proceedings for winding up need not be transferred to NCLT under the IBC.

${ }^{43}$ Sree Shanumgar Mills Ltd. v. Darmaraja Nadar A.LR. 1970 Mad. 203.

${ }^{44} I d$.

${ }^{45}$ Tata Iron Steel and Co. v. Micro Forge (India) Ltd., [2001] 104 Comp Cas 533 (Guj).
} 
means it cannot be characterized as a standalone ground." 46 Meaning, that once a debt is undisputed, commercial solvency of the debtor cannot be taken as a defense to avoid winding up, thereby reducing the scope for any potentiality of balance sheet insolvency.

The Supreme Court in Mobilox Innovations ${ }^{47}$, when faced with insolvency application under the IBC clarified by taking reference of the BLRC Interim Report that the IBC only provides for a default-based cash flow test, without any discussion on the same. In 2019, the Supreme Court in Jignesh Shah was faced with the constitutional validity of applicability of Limitation Act, 1963 on insolvency proceedings, arising due to transfer of winding up petition as insolvency application under IBC. It provided guidance as an obiter over the exact triggering point of insolvency under the cash flow test as "the date on which default is committed, on account of which the company is unable to pay its debts which is a fixed date that can be proved on the facts of each case" 48 , thereby affirming the genesis of cash flow insolvency as highlighted above. Such broad and vastly contradicting approaches taken by different Courts, including the Supreme Court not only renders liquidation ineffective as a disciplinary mechanism but also casts serious doubts over the understanding of the nature of these insolvency tests under the Indian jurisprudence. The relevance of these case laws and the positions after the IBC's enactment is detailed in the final section.

\section{Application of insolvency tests in US and UK}

\subsection{United States:}

In the United States, bankruptcy and insolvency is covered under three legal regimes: US Bankruptcy Code (UBC) [1978], Uniform Commercial Code (UCC) [1952] and Uniform Fraudulent Conveyance Act, 1918 (UFCA). While the recourse to UBC is taken by both debtors and creditors to declare insolvency, the reference to UFCA is made to void the avoidable transactions outside of bankruptcy. ${ }^{49}$ Under Section 101(32) of the UBC, a company is declared insolvent at fair valuation when the entity's debts are greater than all of its property.

\footnotetext{
46 IBA Health v. Info-Drive Systems, [2010]159 CompCas 369(SC).

${ }^{47}$ Mobilox Innovations Private Ltd v. Kirusa Software Private Ltd, Civil Appeal No. 9405 of 2017.

48 Jignesh Shah v. Union of India, (2019) 10 SCC 750. Here, a winding up petition under CA, 2013 was filed before the Bombay $\mathrm{HC}$ against the debtor and consequently post enactment of the IBC, it was transferred to the NCLT.

${ }^{49}$ It should be noted that prior to the UBC, there was no definite conception of insolvency and fraudulent conveyances arising out of insolvencies was governed by the UFCA. However, post the UBC, all avoidable conveyances are governed itself.
} 
Thus, on prima facie view the UBC applies the balance sheet test to determine insolvency of the corporation. ${ }^{50}$ While, fair valuation implies the fair market value of the corporation's assets that can be achieved if sold on going concern basis. ${ }^{51}$ While Section 28:1-201(23) of the UCC declares insolvency as inability to pay debts as they fall due, Section 6 of the UFCA takes into consideration both "present" and "future" creditors using the cash flow test. ${ }^{52}$ This shows that the determination of insolvency under the UFCA is broader than the UBC, implying additional duties upon the board of directors of the debtor to indulge in avoidable transactions even where there is possibility of cash flow insolvency. ${ }^{53}$ Therefore the balance sheet test is utilized under the UBC whereas for purposes of avoidable transactions, reference to both cash flow and balance sheet test is taken as per the UFCA. ${ }^{54}$ UCC's Official Comment 23 to Section 1-201 states that the tests of insolvency under the UCC is accorded as alternative test and taken recourse from commercial standing of the parties to the dispute..$^{55}$

Under the US insolvency regime, contrary to the position of the UK, cash flow test is considered as an equitable remedy and largely broader in scope than the balance sheet test. ${ }^{56}$ Accordingly, cash flow test in the US is not only a positive determination of insolvency but also takes into consideration both current and prospective obligations. The judicial law; however, is unclear as to the forward-looking nature of the cash flow test taking into consideration the mingled definition under the $\mathrm{UFCA}^{57}$. While the UBC incorporates a uniform balance sheet test; however, in practice, the requirement of fair valuation results in inclusion of factors not being part of the balance sheet. ${ }^{58}$ The bankruptcy courts thus take into consideration contingent assets and liabilities of the debtor corporation, resulting in according subjectivity to the reorganization process, leading to frequent solvency disputes surrounding

\footnotetext{
${ }^{50}$ Langham, Langston \& Burnett v. Blanchard, 246 F.2d 529 (5th Cir. 1957).

${ }^{51}$ In re Roblin Indus. Inc., 91 CV 523A (W.D.N.Y. 1995).

${ }^{52} \S 6$ of the Uniform Fraudulent Conveyance Act, 1918 "The person making the conveyance... believes he will incur debts beyond his ability to pay as they mature, is fraudulent as to both present and future creditors,"

${ }^{53}$ William K. Lenhart \& Jack F. Williams, You Are Now Entering the Insolvency Zone, Turnaround Management Spring (2004).

54 The reference of insolvency test under the UCC for purposes of bankruptcy remains limited to academic discussion. Alemante G. Selassie, Valuation Issues in Applying Fraudulent Transfer Law to Leveraged Buyouts, 378 Boston College Law Review (1991).

${ }^{55}$ Ronald J. Mann, Elizabeth Warren, Jay Lawrence Westbrook, Comprehensive Commercial Law: 2017 Statutory Supplement, Wolters Kluwer Law \& Business (2017)

${ }^{56}$ Lumber Co. v. Holley, 224 N.E.2d 360 (Ohio Ct. App. 1967). See also. Jack Williams, Revisiting the Proper Limits of Fraudulent Transfer Law, 8 Emory Bankruptcy Developments Journal 55 (1991)

${ }^{57}$ Angelo, Gordon \& Co. L.P. v. Allied Riser Commc'ns Corp., 805 A.2d 221 (Del. Ch. 2002); Richard Cieri \& Michael Riela, Protecting Directors and Officers of Corporations That Are Insolvent or in the Zone or Vicinity of Insolvency: Important Considerations, Practical Solutions, 2 DePaul Business and Commercial Law Journal 295 (2003-2004).

${ }^{58}$ Peitz v. Hatten, 279 B.R. 710,743 (Bankr. D. Del. 2002).
} 
appropriate valuation. ${ }^{59}$ Thus at the first instance and for purposes of valuation, balance sheet test is utilized to ascertain insolvency of the debtor corporation and cash flow test is utilized for determination of any preference during relevant look back period by the debtor corporation. ${ }^{60}$

\subsection{United Kingdom:}

The UK bankruptcy law had a significant influence in the development of the law of corporate liquidation. Historically, the law applicable to individual traders and partnerships applied to insolvent corporations. ${ }^{61}$ Throughout the $18^{\text {th }}$ century development of bankruptcy legal regime in the UK, the two insolvency tests were never statutorily incorporated, ${ }^{62}$ courts decided cases based on individual circumstances. ${ }^{63}$ There was practically no similarity with the modern regime of insolvency, as provided under the IA 1986, for the want of collective mechanism for debt recovery and creditors could not enforce the debt against most of the assets of the debtors. ${ }^{64}$ While the balance sheet insolvency was first codified through the Companies Act, 1907, it was under the Companies (Consolidation) Act 1908 that the contingent and prospective creditors were granted statutory and not equity locus standi to present a winding up petition. ${ }^{65}$ Gradually Courts started to consider prospective debts and liabilities of the debtor company for purposes of determination of winding up. ${ }^{66}$ After the enactment of the Insolvency Act 1986 in UK (IA 1986), a clear distinction was made between cash flow and balance sheet tests. ${ }^{67}$

Before the enactment of the IA 1986 there was no strict differentiation between the two tests under the English law, and the balance sheet test was successfully used and significantly

\footnotetext{
${ }^{59}$ Jay Lawrence Westbrook, A Global View of Business Insolvency Systems, Martinus Nijhoff Publishers (2010)

${ }^{60}$ Robert J. Stearn \& Cory D. Kandestin, Delaware's Solvency Test: What Is It And Does It Make Sense? A Comparison Of Solvency Tests Under The Bankruptcy Code And Delaware Law, 36 Delaware Journal of Corporate Law 166 (2011)

${ }^{61}$ W. Horrwitz, Historical Development of Company Law, 62 Law Quarterly Review 375 (1946).

${ }^{62}$ Lacey v. Hill, 1870 L.R. 18 Eq. 182.

${ }^{63}$ I. Treiman, Acts of Bankruptcy: A Medieval Concept in Modern Bankruptcy Law, 52 Harvard Law Review 189 (1938).

${ }^{64}$ Robert Weisberg, Commercial Morality, the Merchant Character, and the History of the Voidable Preference, 39 Stanford Law Review 3 (1986); Christopher Mallon \& Shai Waisman, The Law and Practice of Restructuring in the UK and US, Oxford Publications (2011).

${ }^{65}$ See, Stonegate Securities Ltd v Gregory [1980] Ch 576 The expression "contingent creditor" refers to creditors in respect of a debt which will only become due in an event which may or may not occur; and a "prospective creditor" is a creditor in respect of a debt which will certainly become due in the future, either on some date which has been already determined or on some date determinable by reference to future events. Until the enactment of the Companies (Consolidation) Act, 1908, the locus standi for these creditors to present winding-up claims varied upon case-to-case basis and the discretion of the Court was exercised as a matter of equity. See. Francis Palmer, The Companies Act 1907 and the Limited Partnerships Act 1907, 2 Stevens and Sons (1908).

${ }^{66}$ Insurance Commissioner v. Associated Dominions Assurance Society Ltd., (1953) 89 C.L.R. 78.

${ }^{67}$ Peter Walton, Inability to pay Debts: Beyond the Point of No Return? 212 Journal on Business Law (2013).
} 
interpreted for the first time by English courts in $2008 .{ }^{68}$ Prior to the IA 1986 the law governing insolvency in the UK did not expressly segregate cash flow and balance sheet insolvency. ${ }^{69}$ Under Section 123 of the IA, 1986 deals with the inability to pay debts where clause (1)(e) deals with the classical cash flow test and clause (2) deals with the balance sheet test for determination of insolvency of the debtor company. The tests introduced under IA 1986 are free-standing tests, meaning either of them are sufficient to establish insolvency although, in some instances, both need to be satisfied. ${ }^{70}$ The provisions of these tests were largely incorporated from the Companies Act, 1862 and the procedural requirements to be met by the creditors remained same as well.

However, it was only in Cheyne Finance ${ }^{71} \&$ Eurosail $^{72}$ that the balance sheet tests was successfully used and significantly interpreted. The backdrop to this change in legal position was the impact of mortgaged-based securities during the 2007-08 global financial crisis, resulting in balance sheet insolvency of many otherwise successful corporations ${ }^{73}$. In Cheyne Finance, the England \& Wales High Court (EWHC) intertwined the cash flow and balance sheet tests by holding that former is not to be determined by mere focus on present debts but also included future elements. ${ }^{74}$ In effect, recourse to balance sheet insolvency by creditors was made easier. Similarly, the UK Supreme Court (UKSC) in Eurosail overturned the test of "point of no return" by the Court of Appeal to interpret it as "balance of probabilities"75, thereby making it difficult for creditors to put reliance on any single test in isolation. The

\footnotetext{
${ }^{68}$ In Re Cheyne Finance, [2007] EWHC 2402 (Ch).

${ }^{69}$ The Enterprise Act, 2002 expedited the insolvency resolution process as envisaged under the IA 1986. The recently introduced Corporate Insolvency and Governance Act, 2020 (CIGA) made certain permanent changes to the IA 1986, in addition to the temporary measures in response to COVID-19. They include ensuring supply of essential goods and services, thereby restricting a supplier's ability to terminate during insolvency resolution process. It has also provided for a moratorium on filing legal, regulatory and administrative proceedings against the debtor for period of 20 days, extendable with creditor consent till 12 months, during insolvency resolution process.

${ }^{70}$ Alexandra Rhim, Reorganization Schemes under U.K. Insolvency Act of 1986: Chapter 11 as a Springboard for Discussion, 16 Loyola of Los Angeles International and Comparative Law Review 985 (1994).

${ }^{71}$ In Re Cheyne Finance, [2007] EWHC 2402 (Ch).

72 BNY Corporate Trustee Services Limited v Eurosail, [2013] UKSC 28.

${ }^{73}$ MM Parkinson, Corporate Governance in Transition: Dealing with Financial Distress and Insolvency in UK Companies, Palgrave Macmillan Springer (2018).

${ }^{74}$ Andrew Keay, Challenging Payments made by Insolvent or Near Insolvent Companies, 3 Nottingham Insolvency and Business Law Journal 11 (2015)

${ }^{75}$ While there was no elaboration over the expression "point of no return" by the Court of Appeal; however, in common practice it implies that there are no favourable future prospects for the company as going concern and liquidation is the sole resort for repayment to debtors. See. Sandra Frisby, Insolvency Law and Insolvency Practice: Principles and Pragmatism Diverge?,64 Current Legal Problems 1 (2011). The UKSC noted this lacunae and overturned the test to "balance of probabilities" where it is to be considered that on the balance of probabilities, a company has sufficient assets to meet all its liabilities, including prospective and contingent liabilities. See. William Day, Taking Balance Sheet Insolvency beyond the Point of No Return, 72 The Cambridge Law Journal 3 (2013).
} 
Eurosail approach is still applied by the courts by not mechanistically applying the test but having regards to commercial reality of the debtor company. ${ }^{76}$ Thus the UK Courts now look at the debtor's finances from a commercial and overall perspective and consider the facts of each case individually. ${ }^{77}$ Prior to the Cheyne Finance and Eurosail Judgments, both the tests were considered tests of commercial insolvency based on single default, where a proof of the debtor's failure to meet a demand to pay an undisputed debt was sufficient to deem insolvency. ${ }^{78}$ The Eurosail judgment interpreted the balance sheet test under the IA 1986 to mean that there must be more than one default by the debtor to initiate insolvency proceedings, distinguishing the single default nature of cash flow test. ${ }^{79}$ While it may be seen that the Eurosail adopted the US interpretation of cash flow test to consider future debts, the position in UK law was already settled and certain as Courts were not required to take into account future debts. ${ }^{80}$ Thus, any incident of non-payment of debt upon demand would be deemed commercially insolvent. ${ }^{81}$

In summary, the US statutory corporate insolvency law, being the foundation of modern insolvency regime incorporates the balance sheet test and the cash flow test being available as an equitable remedy for determining fraudulent preferences. Contrastingly, the UK statutory law incorporates the cash flow and balance sheet test separately, unlike the mixed provision, which can be resorted to by creditors as per the given facts and circumstances. Other jurisdictions for example, the Australian Corporations Act, 2002 provides for the cash flow test. However, for the purposes of valuation of the assets of the debtor, reference to the balance sheet test is resorted to by creditors ${ }^{82}$. Similarly, the Singaporean Insolvency and Restructuring

\footnotetext{
${ }^{76}$ From judicial perspective, "commercial reality" implies consideration of the company's finances from an overall understanding without strict regard to theoretical analysis. See. Donna Union Foundation v. Koshigi Ltd., BVIHC (COM) 231 of 2018; Re HLC Environmental Projects Ltd [2013] EWHC 2876 (Ch), [2014] BCC 337 [81]; Evans v Jones [2016] EWCA Civ 660, [2017] Ch. 1; Re Rococo Developments Ltd [2016] EWCA Civ 660, [2017] Ch. 1, [24].

${ }^{77}$ BTI 2014 LLC v Sequana SA, [2016] EWHC 1686 (Ch).

${ }^{78}$ In the Matter of Okyanos Operating Company Ltd., 2019/COM/com/00891; Re Globe New Patent Iron \& Steel Co, (1875) LR 20 Eq 337.

${ }^{79}$ Meng Seng Wee, Understanding Commercial Insolvency and Its Justifications as a Test for Winding Up, 62 Lloyd's Maritime and Commercial Law Quarterly 84 (2015).

${ }^{80}$ Dina Khairunisyah, The Urgency of Insolvency Test to declare Bankrupt in Indonesia: Applying the Theory of Balance Sheet Test under U.S Bankruptcy Code, Universitas Islam Indonesia (2016); Re European Life Assurance Society, (1869) LR 9 Eq 122.

${ }^{81}$ Re Imperial Hydropathic Hotel Co, Blackpool Ltd (1882) 49 LT 147; Meng Seng Wee, Understanding Commercial Insolvency and Its Justifications as a Test for Winding Up, 62 Lloyd's Maritime and Commercial Law Quarterly 84 (2015).

82 Under the Australian approach, the cash flow test being a statutory test is only the starting point for determination of solvency and reference to balance sheet is taken to understand the nature of the business. The determination of insolvency and its application under the individual insolvency law had a significant impact upon the enactment of the incumbent Corporations Act, 2001. The phrase :inability to pay its debts" was interpreted for the first time in Bank of Australasia v Hall, [1907] 14 ALR 51 to mean "the debtor's position depends on whether
} 
Dissolution Act, $2020^{83}$ despite envisaging a mixed provision of both the tests in a single provision provides for remedies against recalcitrant debtors. ${ }^{84}$

Thus, the above analysis of U S and U K jurisdictions, and to an extent Australia and Singapore shows that while the statute law may provide recourse to either of the two tests; however, in judicial practice, reference is made to both the tests to effectuate fair and equitable resolution. Moreover, and importantly, such divergent statutory incorporations of these tests also provide scope to understand their impact on avoidable transactions, which is detailed in the next section.

\section{Impact of Tests beyond Determination of Solvency}

While formal insolvency proceedings may take time to crystallize, the board of directors most often are well aware of the state of insolvency for the company. During such stage, there may be significant opportunities for the debtor company to reduce the liquidation estate or dispose

he can pay his debts, not on whether a balance sheet will show a surplus of assets over liabilities." See. David Morrison, When is a Company Insolvent, 10 Insolvency Law Journal (2002). Interestingly by then, the law on corporate insolvency is yet to be evolved and there was no reliance on any particular test on insolvency as applied in the modern context. The phrase continued its existence with Section 95(1) of the Bankruptcy Act, 1924 and the Bank of Australasia interpretation was expanded in Rees v. Bank of New South Wales, [1965] ALR 139 and Sandell v. Porter to mean, " a temporary lack of liquidity, if viewed in isolation from the surrounding circumstances, might give rise to an inaccurate conclusion of insolvency. "This lack of codification of the balance sheet test continued with the law on corporate insolvency as well under Section 95A of the CA, 2001, despite express recommendation of the Harmer Committee for incorporation of both the tests as separate grounds. Accordingly, the expansive incorporation of the non-existent balance sheet test under the cash flow test was highlighted again in Southern Cross v. DCT, (2001) 39 ACSR 305.The Courts gradually started placing reliance not only on contingent liabilities of the debtor but also prospective liabilities and assets for purposes of insolvency determination and similarly, debts presently due and those about to become due in the near future were considered as well.

83 The Insolvency, Restructuring and Dissolution Act, 2020 (IRDA) based upon the erstwhile Companies Act 2006 (CA 2006) provides for a combined test of cash flow and balance sheet. The judicial precedents as well as scholars opined that the test u/s. 254(2)(c) of the CA 2006 was cash flow test and didn't contemplate about the balance sheet solvency. This position however changed in In Re Great Eastern Hotels, (1988) SLR 276 (HC) and was inspired by the English and Australian precedents. Simply put, the debtor is not insolvent if it is proved that it has sufficient liquid assets to meet demands for repayment by the creditors and the fact that the debtor doesn't have sufficient liquid cash becomes irrelevant. See. Tong Tien See Construction Pte Ltd (in liquidation) v. Tong Tien See [2001] 3 S.L.R.(R.) 887 (H.C.). Following BNP Paribas v. Jurong Shipyard Pte Ltd. [2009] SGCA 11 the subjectivity of balance sheet test was instilled whereby it has become uncertain if a single instance of inability to pay debt would suffice to declare insolvency and determination has to be based upon individual facts. Thus, when a debtor company has failed to repay an undisputed debt, the creditor would be entitled to make a winding up application; however, when the debtor has been recalcitrant, it may choose not to repay the debt by offering security for the debt reasonable to the discretion of the Court. See. Lee Eng Beng \& Kevin Poon, Insolvency Law, 10 Singapore Academy of Law Annual Review of Singapore Cases 340 (2009) and Andrew Chan, Global and Regional Practices in Financial Restructuring and Bankruptcy Laws: Lessons to Be Learned from Singapore in Hajjiri T.M., Cohen A. (eds) Global Insolvency and Bankruptcy Practice for Sustainable Economic Development, Macmillan (2016).

${ }^{84}$ See. Section 125(2)(c) - A company is deemed unable to pay its debts if it is proved to the satisfaction of the Court that the company is unable to pay its debts; and in determining whether a company is unable to pay its debts the Court must take into account the contingent and prospective liabilities of the company. 
business assets to relatives or to repay some friendly creditors in preference to others. ${ }^{85}$ Such transactions are avoidable in nature and can be restrained through the assistance of the insolvency administrator or the Courts which take into consideration certain criteria for determination. ${ }^{86}$ The avoidable transactions can be either preferential, or fraudulent, or undervalued. In Preferential transactions, the debtor gives a preference in terms of payment or property to a certain favorable creditor over other creditors, resulting in the latter being obligated to take reduced payments. ${ }^{87}$ Fraudulent transactions or wrongful trading occurs when the business of the debtor is being carried on to defraud creditors and the board of directors of the debtor company being aware of the financial condition indulges in transaction for want of due diligence and care entrusted upon them. ${ }^{88}$ In undervalued transactions, the property of debtor is sold off to a favorable party for price lower than the market value to the detriment of creditors from which they could have realized their debts. ${ }^{89}$ Such unethical malpractices are condemned by insolvency and liquidation law and the nature of remedy lies in the fact that the party which has benefited from the transaction has to vest the property back to the debtor for realization by creditors ${ }^{90}$. The board of directors of the debtor as well as any third-party which received benefit can be made liable for entering into such transactions. ${ }^{91}$

\subsection{Fiduciary duty, avoidance transactions and rights of creditors}

As observed in the initial part of the paper, the significance of insolvency tests goes beyond mere determination of insolvency of the debtor. This section will detail how these tests, as a diagnostic measure, can help in determining remedial measures for the creditors. Aurelio Gurrea-Martínez argues that a combination of insolvency tests can help reduce litigation costs associated with proving of avoidable transactions by determining a short look back period and entrusting the administrator to challenge their validity. ${ }^{92}$ Further, the reasonable time period must be observed from the view of creditors, who may require longer time to avoid the

\footnotetext{
${ }^{85}$ UNCITRAL Legislative Guide, Pg. 135 para 148.

${ }^{86}$ Gerard McCormack, Universalism in Insolvency Proceedings and the Common Law, 32 Oxford Journal of Legal Studies 2 (2012)

${ }^{87}$ Kristin van Zwieten, Related Party Transactions in Insolvency, European Corporate Governance Institute Working Paper No. 401/2018.

${ }^{88}$ Samuel Caulfield, Fraudulent and Preferential Conveyances of the Insolvent Multinational Corporation, 17 New York Law School Journal of International and Comparative Law 571 (1997)

${ }^{89}$ John Armour \& Howard Bennett, Vulnerable Transactions in Corporate Insolvency, Bloomsbury Publishing (2003).

${ }^{90}$ UNCITRAL Legislative Guide, Pg. 121-122 para 202.

${ }^{91}$ Paul Ellington \& Ian Fletcher, Responsibility and Liabilities of Directors and Officers of Insolvent Corporations, 16 International Business Lawyer 491 (1988).

92 Aurelio Gurrea-Martínez, The Avoidance of Pre-Bankruptcy Transactions: An Economic and Comparative Approach, 93 Chicago Kent Law Review 711 (2018)
} 
distressed transfer of property by the debtor and shorter time period to preserve maximum value of assets. ${ }^{93}$ To address this inconsistency, in United States, the Section 547(f) of the UBC provides a statutory presumption of insolvency where the debtor corporation will be presumed insolvent 90 days before the application for preferential transaction is initiated. Such a presumption is rebuttable where the debtor corporation brings forward credible evidence suggesting that it is not insolvent 90 days prior to the application. ${ }^{94}$ The rebuttal of presumption can be proved through preponderance of probabilities and reasonable certainty is not expected of the debtor corporation. ${ }^{95}$ For e.g. X Ltd. was held insolvent by the insolvency court on $4^{\text {th }}$ November, 2016 and the insolvency administrator will take into consideration transactions entered by the debtor for period of 90 days prior to $4^{\text {th }}$ November, 2016. If X Ltd. proves that it wasn't aware of the impeding circumstances which resulted in insolvency, then it will be given the benefit. Thus, the balance sheet test incorporated under section 101(32) of the UBC is applied for avoiding preferential transactions. In respect of fraudulent transactions, S.548 states that the bankruptcy trustee may make an application for avoiding fraudulent transfers when the debtor is unable to pay its debts as they fall due, thereby incorporating cash flow test for avoiding these transactions. ${ }^{96}$ For purposes of practical application it must be noted that avoidance applications under section 548 is quite rarely litigated by the bankruptcy trustee on account of the subjective nature of the inquiry. ${ }^{97}$ A probable response for incorporation of different tests for preferential and fraudulent transactions relates with the aspect of lack of look back period in the latter and the arbitrary and misleading nature of the mechanical balancesheet test of insolvency. ${ }^{98}$

In comparison, while Section 123 of the IA 1986 in the UK incorporates both balance sheet and cash flow test separately, for purposes of wrongful trading under section 214 of the IA 1986, it only recognizes the balance sheet test. ${ }^{99}$ Thus, the law does not require the debtor going

\footnotetext{
${ }^{93}$ In re Trans World Airlines, 145 F.3d 124 (1998).

${ }^{94}$ Argus Mgmt Group v. J-Von N.A. (in re CVEO Corp.), 327 B.R. 724, 729 (Bankr. D. Del. 2005)

${ }^{95}$ In re American Classic Voyages Co., 2007 WL 123782; In re Zeta Consumer Prods. Corp., 291 B.R. at 347.

${ }^{96}$ Morse Operations, Inc. v. Goodway Graphics of Va., Inc. (in re Lease -A-Fleet, Inc.), 155 B.R. 666, 675 (Bankr. E.D. Pa. 1993)

${ }^{97}$ Robert J. Steam, Proving Solvency: Defending Preference and Fraudulent Transfer Litigation, 62 The Business Lawyer 359, 365-66 (2007).

${ }_{98}$ Robert Charles Clark, The Duties of the Corporate Debtor to Its Creditors, 90 Harvard Law Review 3 (1977)

${ }^{99}$ Hans Hurt, The Wrongful Trading Remedy in UK Law: Classification, Application and Practical Significance, 1 European Company and Financial Law Review 71 (2004).

Insolvency Act, 1986 Section 213, Fraudulent trading:(1)If in the course of the winding up of a company it appears that any business of the company has been carried on with intent to defraud creditors of the company or creditors of any other person, or for any fraudulent purpose, the following has effect. (2)The court, on the application of the liquidator may declare that any persons who were knowingly parties to the carrying on of the business in the
} 
into insolvent liquidation as the trigger point; however, formal liquidation proceedings is a prerequisite for the enforcement duties towards creditors. ${ }^{100}$ Such divergent test for determination creates a peculiar situation where there is lack of clarity of triggering of duties of debtors towards creditors when the former is cash flow insolvent but balance sheet solvent. ${ }^{101}$ The scholarly discourse in the context of avoidable transactions suggests otherwise that the subjective nature of the cash flow test should be avoided and the objectivity ascertained through the balance sheet test should be utilized for the purposes of insolvency requirement. ${ }^{102}$ Prior to the recognition of director's liability in insolvency (trust fund doctrine) the established position was that the Courts refused to extend fiduciary duties of the debtor for the benefit of creditors and creditors' rights were to be exclusively governed by the terms of their contracts. ${ }^{103}$ The trust fund approach in simple terms triggers only upon actual event of insolvency and as we have seen before that on account of lack of clarity towards determination of actual insolvency, it results in increase in litigation costs. ${ }^{104}$ The roots of the trust fund doctrine lies in Wood v. Drummer where an insolvent bank declared a liquidating dividend towards its shareholders to the prejudice of its creditors. Creditors petitioned the bank for avoiding the payment of dividend and the Court held that "the capital stock of insolvent entities is deemed to be a pledge or trust fund for the payments of the debts contracted." 105 The trust fund doctrine rapidly evolved and the Courts started applying it in circumstances beyond anticipated insolvency to hold the directors of debtor entity guilty for carelessness towards their insolvent duties. ${ }^{106}$ However, in the absence of bad faith and in the ordinary course of the business of the debtor, the debtor was not liable for any preference or undervaluation. ${ }^{107}$

\footnotetext{
manner above-mentioned are to be liable to make such contributions (if any) to the company's assets as the court thinks proper.

Section 214 Wrongful trading: (2)This section applies in relation to a person if - (a)the company has gone into insolvent liquidation, $(b)$ at some time before the commencement of the winding up of the company, that person knew or ought to have concluded that there was no reasonable prospect that the company would avoid going into insolvent liquidation, and (c)that person was a director of the company at that time;

${ }^{100}$ Paul Davies, Directors' Creditor-Regarding Duties in Respect of Trading Decisions Taken in the Vicinity of Insolvency, European Business Organization Law Review (2007)

${ }^{101}$ Re Rod Gunner Organisation, [2004] 2 BCLC 110.

${ }^{102}$ Lee Eng Beng, The Avoidance Provisions of the Bankruptcy Act 1995 and their Application to Companies, Singapore Journal of Legal Studies (1995).

${ }^{103}$ Katz v. Oak Industries, Inc., 508 A.2d 873 (Del. Ch. 1986).

${ }^{104}$ Neil Ruben, Duty to Creditors in Insolvency and the Zone of the Insolvency: Delaware and the Alternative, 7 New York University Journal of Law and Business 333 (2011)

105 Wood v. Drummer, 30 F. Cas. at 435.

${ }^{106}$ Richard Cieri \& Michael Riera, Protecting Directors and Officers of Corporations That Are Insolvent or in the Zone or Vicinity of Insolvency: Important Considerations, Practical Solutions, 2 DePaul Business and Commercial Law Journal 295 (2004)

${ }^{107}$ Asmussen v. Quaker City Corp., 156 A. 180 (Del. Ch. 1931).
} 
This lack of clarity over triggering of insolvent duties for the debtor on actual happening of the insolvency, or on the commencement of a formal insolvency proceeding before courts was resolved in favour of the former, resulting in formation of presumptive look back period. ${ }^{108}$ The roots of formation of the presumptive statutory look back period lie in Credit Lyonnaies where the Courts for the first time extended insolvency duty beyond insolvency to instances where debtor corporations remained in the shadow of insolvency. ${ }^{109}$ The decision in Credit Lyonnaies over the years brought out divergent views, leading to expansive interpretation by Courts, eventually resulting in it being overruled by the Delaware Supreme Court, as discussed below in succeeding paragraphs. One interpretation is that the judgment as just an expansion of scope of insolvent duties from insolvency in fact to near-insolvency, the roots of both are derived from the equitable trust law. ${ }^{110}$ The most immediate implication of such radical interpretation was that Courts now were not obligated to distinguish between the instances of factual happening of insolvency and breach of fiduciary duties against the board of directors.. ${ }^{111}$ The second, aware of the potential variability that an affirmative duty towards creditors would create, restricted the application of the doctrine where the creditors can evidence actual fraud or preference. ${ }^{112}$ Thus, the creditors were required to prove that the fraudulent act involved the disposal of assets for the benefit of shareholders, but to the prejudice of the "entire" corporate enterprise instead of "any" particular creditor class. ${ }^{113}$ The third view regarded Credit Lyonnaies as operating as a shield for directors of the debtor instead of providing justification for extension of fiduciary duties towards creditors. ${ }^{114}$ Thus, the interpretation relied upon the existence of alternative remedies Credit Lyonnaies "is using the law of fiduciary duty to fill gaps that do not exist" and creditors already possess statutory protections for avoidable transactions under the law on implied covenants of good faith and fraudulent conveyance. ${ }^{115}$ The Delaware Supreme Court later effectively overruled Credit Lyonnaies in NACEP $v$.

\footnotetext{
108 Geyer v. Ingersoll Publ'ns Co., 621 A.2d 784 (Del. Ch. 1992).

${ }^{109}$ Credit Lyonnais Bank Nederland, N.V. v. Pathe Comm. Corp., Del. Ch. Dec. 30, 1991.

${ }^{110}$ Weaver v. Kellogg, 216 B.R. 563, 583-84 (Bankr. S.D. Tex. 1997); Peoples Dep't Stores, Inc. (Trustee of) v. Wise, [2004] 3 S.C.R. 461, 493 (Can.).

${ }^{111}$ Official Comm. of Unsecured Creditors of Buckhead Am. Corp. v. Reliance Capital Group, Inc. (In re Buckhead Am. Corp.), 178 B.R. 956, 968 (Bankr. D. Del. 1994).

${ }^{112}$ Steinberg v. Kendig (In re Ben Franklin Retail Stores, Inc.), 225 B.R. 646, 655-56 (Bankr. N.D. Ill. 1998);

Vincent Buccola, Beyond Insolvency, 62 University of Kansas Law Review 1 (2013-2014)

${ }^{113}$ Laura Lin, Shift of Fiduciary Duty upon Corporate Insolvency: Proper Scope of Director's Duty to Creditors, 46 Vanderbilt Law Review 1485 (1993).

${ }^{114}$ Production Resources Group, L.L.C. v. NCT Group, Inc., 863 A.2d at 772.

${ }^{115}$ Mims v. Kennedy Capital Mgmt., Inc. (In re Performance Nutrition Inc.), 239 B.R. 93, 111 (Bankr. N.D. Tex. 1999)
} 
Gheewala $^{116}$ holding that the former created such a situation wherein challenge to every corporate transaction in zone of insolvency was challenged as being avoidable. ${ }^{117}$ Thus, since then creditors are barred from initiating direct legal action during the zone of insolvency for avoidable transactions and only derivative action claims can be initiated only on grounds of actual and demonstrable harm to corporate asset. ${ }^{118}$

\subsection{Scheme of avoidance transactions under the Indian regime}

One may opine that unlike the US and UK laws, the role of insolvency tests under the IBC is limited to determination of default and doesn't play any role regarding the avoidance transactions. Since the jurisprudence on the subject is yet to be developed in India, an extensive discourse on the same falls outside the scope of this paper. The scheme of avoidance transactions under the IBC considers four distinct categories of transactions which can be avoided and appropriate recovery orders can be passed by the Adjudicating Authority - (a) preferential (b) undervalued (c) extortionate and (d) fraudulent transactions. ${ }^{119}$ While an undervalued transaction under section 47 of $\mathrm{IBC}^{120}$ can be challenged by both the resolution professional and the creditors, an offending preference can only be challenged by the former under section. 43 of IBC $^{121}$. There must be a definite transfer of property of the corporate debtor in favour of the creditors either on account of an antecedent liability or beneficial position in respect of the distribution assets during liquidation in case of preference whereas a transfer as gift or for price significantly less than original purchase price with respect to undervalued

\footnotetext{
${ }^{116}$ North American Catholic Educational Programming Foundation Inc. v. Gheewalla, 930 A.2d 92, 101 (Del. 2007).

${ }^{117}$ Bryan Anderson, Gheewalla and Insolvency: Creating Greater Certainty for Directors of Distressed Companies, 11 University of Pennsylvania Journal of Business Laws 1031 (2008-2009).

${ }^{118}$ Quadrant Structured Products Company, LTD, 115 A.3d 535 (2015); Berg \& Berg Enter., LLC v. Boyle, 178 Cal. App. 4th 1020 (Cal. Ct. App. 2009).

${ }^{119}$ Arnav Maru \& Bhavya Solanki, Avoidance Proceedings under the IBC: Time for a Tweak in the Regime?, IndiaCorpLaw (2020), available at https://indiacorplaw.in/2020/05/avoidance-proceedings-under-the-ibc-timefor-a-tweak-in-the-regime.html

${ }^{120}$ IBC Section 47. (1) Where an undervalued transaction has taken place and the liquidator or the resolution professional as the case may be, has not reported it to the Adjudicating Authority, a creditor, member or a partner of a corporate debtor, as the case may be, may make an application to the Adjudicating Authority to declare such transactions void and reverse their effect in accordance with this Chapter. (2) Where the Adjudicating Authority, after examination of the application made under sub-section (1), is satisfied that - (a) undervalued transactions had occurred; and (b) liquidator or the resolution professional, as the case may be, after having sufficient information or opportunity to avail information of such transactions did not report such transaction to the Adjudicating Authority.

${ }^{121}$ IBC Section 43. (2) A corporate debtor shall be deemed to have given a preference, if- (a) there is a transfer of property or an interest thereof of the corporate debtor for the benefit of a creditor or a surety or a guarantor for or on account of an antecedent financial debt or operational debt or other liabilities owed by the corporate debtor; and (b) the transfer under clause (a) has the effect of putting such creditor or a surety or a guarantor in a beneficial position than it would have been in the event of a distribution of assets being made in accordance with section 53 .
} 
transactions. ${ }^{122}$ These transactions however cannot be avoided when undertaken as part of "the undistinguished common flow of business" or within the ordinary course of the business. ${ }^{123}$

Section 66(1) of IBC providing for fraudulent trading is broad enough to even hold outsiders of the company liable as long as they had a dishonest intention of fraudulently carrying on trade. ${ }^{124}$ For wrongful trading under section 66(2) however, only the board of directors of the debtor can be held liable if they had actual or constructive knowledge of no reasonable prospect of avoiding the insolvency and they did not exercise due diligence in minimising the potential loss to the creditors. ${ }^{125}$ Thus, directors can be liable under section 66(2) even if they did not have a dishonest intention, but acted negligently and recklessly. ${ }^{126}$ The modern insolvency laws which includes provisions on avoidable transactions take into consideration most of the considerations discussed by the Courts by provisioning for statutory look back presumption, consolidating of laws on liquidation and fraudulent transfers and authorizing not the creditors but the insolvency administrator to initiate claims on behalf of creditors. ${ }^{127}$

\section{Insolvency and Bankruptcy Code and way forward}

Indian cases that discussed in part 3 of this paper were largely under the CA 1956 \& 2013 that revolved around the statutory demand test with very limited authoritative precedent discussing in detail about the mixed provision. ${ }^{128}$ Section $3(12)$ of the IBC deals with the definition of default $^{129}$ in which incorporates only the cash flow test, thereby departing from the conventional practice of incorporating both sides of insolvency tests. In simple terms there has been a shift from "inability" to "failure" as a result of the change from "mixed provision" to the "cash flow test." 130 While the IBC doesn't expressly disregards any interpretation of

\footnotetext{
${ }^{122}$ Abhiman Das et. al, Insolvency and Bankruptcy Reforms: The Way Forward, 45 Vikalpa Journal for Decision Makers, Sage Publications 2 (2020).

${ }^{123}$ Downs Distributing Co Pty Ltd v. Associated Blue Star Stores Pty Ltd., (1948) 76 CLR 463. Followed by the Indian Supreme Court in Anuj Jain, Interim Resolution Professional for Jaypee Infratech Ltd. v. Axis Bank Ltd., Civil Appeal Nos. 8512-8527 of 2019.

${ }^{124}$ Resolution Team Services, A Note on Fraudulent Trading and Wrongful Trading, Vinod Kothari \& Company (2019); Morris v. Bank of India, [2004] 2 BCLC 279.

${ }^{125}$ Priti Paras Savla, Forensic Audit and Transaction Audit under the IBC, Western India Regional Council of The Institute of Chartered Accountants of India (2019).

${ }^{126}$ Bank of India v. IRIS Electro Optics Pvt. Ltd., CA(AT)(IB) No. 49 of 2020.

${ }^{127}$ Cory D. Kandestin, The Duty to Creditors in Near-Insolvent Firms: Eliminating the "Near-Insolvency" Distinction, 60 Vanderbilt Law Review 1235 (2019).

${ }^{128}$ The Interim Report of the BLRC states that, "there has been extensive judicial development with regard to the meaning and interpretation of "commercial insolvency" in the UK post the In Re European Life Assurance Society which does not seem to have been taken into consideration by the Indian courts."

129 "Default" means non-payment of debt when whole or any part or instalment of the amount of debt has become due and payable and is not paid by the debtor or the corporate debtor, as the case may be.

${ }^{130}$ Megha Mittal, Ushering In a New Era: An Anthology of Articles on the Insolvency \& Bankruptcy Code, 2016, Vinod Kothari \& Company (2019).
} 
balance sheet insolvency, however, the Supreme Court in Innoventive Industries held that "the adjudicating authority has merely to see the records of the information utility or other evidence produced by the financial creditor to satisfy itself that a default has occurred. It is of no matter that the debt is disputed so long as the debt is "due" i.e. payable unless interdicted by some law or has not yet become due in the sense that it is payable at some future date. It is only when this is proved to the satisfaction of the adjudicating authority that the adjudicating authority may reject an application and not otherwise." 131 Thus, suggesting that the playing field for the creditors under the IBC unlike Companies Act is very broad and clearly there is no requirement for minimum number of defaults before initiating insolvency.

Despite there being sufficient history of distinction between the cash flow and balance sheet insolvency tests under Companies Act, 1956 and 2013, the IBC clearly excludes the latter as one of the grounds for presenting insolvency resolution petition. The NCLAT in Unigreen Global held that "the Adjudicating Authority on hearing the parties and on perusal of record, if satisfied that there is a debt and default has occurred and the Corporate Applicant is not ineligible under Section 11, the Adjudicating Authority has no option but to admit the application, unless it is incomplete." 132 The NCLAT; however, in Vikas Aggarwal Case, observed that the "corporate debtor is only entitled to point out that the default had not occurred in the sense that the debt in contention is not $d u e^{\$ 133}$, thereby providing a possible scope for pleading for balance sheet insolvency. But the NCLT in the same year in another case conveyed, "even if part of the debt, once becomes payable and remains unpaid it will amount to default under the Code"134, suggesting that when cash flow insolvency is proved, the test of insolvency is met and a probable pleading for balance sheet insolvency may not sustain or even considered. Further, "any fact unrelated or beyond the requirement under the IBC are not required to be stated or pleaded" ${ }^{\prime 135}$, implying that the scope for pleading balance sheet insolvency has been drastically reduced and even if pleaded, the NCLTs do not even have to consider it without reference to cash flow insolvency.

The scope of the balance sheet insolvency test lies in fact that it can also be utilized to resolve immediate structural problem of moratorium on initiation of formal insolvency proceedings as posed by Section $10 A$ of the IBC. Since the focus of the test is on the reasonably foreseeable

\footnotetext{
${ }^{131} \mathrm{M} / \mathrm{s}$. Innoventive Industries Ltd v. ICICI Bank, Civil Appeal No. 8337-8338 of 2017.

132 Unigreen Global Pvt Ltd v. PNB \& Others, Company Appeal (AT) (Insolvency) No.81/2017.

${ }^{133}$ Vikas Aggarwal v. State Bank of India, Company Appeal (AT) (Insolvency) No. 587 of 2018.

${ }^{134}$ Anil Nanda v. Hari Kishan Sharma, Company Appeal (AT) (Insolvency) No. 167 of 2018.

${ }^{135}$ Ameya Laboratories Ltd. v. Kotak Mahindra Bank, Company Appeal (AT)(Insolvency) No.192 of 2017.
} 
future and overall commercial reality of the debtor and not necessarily upon the maturity date of default, Courts will be better placed to ascertain the payment capacity of the stressed debtor with regards to peculiar facts and circumstances of the individual cases on account of the balance sheet test. Further, the incorporation and subsequent application of the balance sheet test results in fulfilment of the objective of the Code to not treat the insolvency mechanism as a recovery tool for creditors alone but for facilitating resolutions by breathing life into the stressed debtor. ${ }^{136}$ Moreover, even, in the absence of any statutory provision providing for balance sheet insolvency, recourse to it for creditors can be allowed for purposes of valuation or as an equitable remedy under the inherent powers of the Courts. ${ }^{137}$

Be that as it may, the insolvency courts including the Supreme Court through the inherent jurisdiction has made expansive interpretations of the provisions of IBC to meet ends of justice. This is done primarily through the Rule 11 of the NCLT Rules, 2016 on account of rapid expansion of jurisprudence under the Code. For instance, the Indian Supreme Court in the Swiss Ribbons Case $^{138}$ affirmed the NCLT's judgment by allowing the creditors to withdraw insolvency resolution under Rule 11 in absence of any express statutory provisions under the IBC. Similarly, in context of substantive law, the NCLT, Mumbai in the landmark judgment in Videocon Case allowed consolidation of insolvency resolution proceedings of group entities to meet ends of justice. ${ }^{139}$ However, it must be noted that such inherent jurisdiction must be exercised with due caution and an inconsistent interpretation in consonance with the express rights or entitlements of the parties should be not utilized. ${ }^{140}$ This shows that there is sufficient scope under the IBC to expand the present regime of insolvency tests under the IBC to include balance sheet insolvency when it meets ends of justice and doesn't result in any inconsistent application of express rights of disputing parties.

\section{Conclusion}

The objective of the Indian IBC is to maximize the value of the corporate debtor's assets for all stakeholders, the debt resolution mechanism therein cannot be divorced from the

\footnotetext{
${ }^{136}$ Binani Industries Limited v. Bank of Baroda., CA (AT) No. 82,123,188,216 \& 234-2018; M. S. Sahoo \& Anuradha Guru, Indian Insolvency Law, 45 Vikalpa Journal for Decision Makers, Sage Publications 2 (2020). ${ }^{137}$ See. Rule 11 of the National Company Law Tribunal Rules, 2016, Inherent Powers.- Nothing in these rules shall be deemed to limit or otherwise affect the inherent powers of the Tribunal to make such orders as may be necessary for meeting the ends of justice or to prevent abuse of the process of the Tribunal.

${ }^{138}$ Swiss Ribbons Pvt. Ltd. v. Union of India, 2019 SCC OnLine SC 73.

${ }^{139}$ State Bank of India v. Videocon Industries Limited, MA 1306/2018 in CP No. 02/2018

${ }^{140}$ Suyash Traders v. Maneklal Enterprises Pvt. Ltd., C.P. 32/58, 59, 397-398/CLB/MB/MAH/2015; Punjab

National Bank v. Vindhya Vasini Industries Limited, C.P. (IB)-1170(MB)/2017.
} 
surrounding realities. Since, the role of insolvency diagnosis doesn't restrict itself to insolvency determination, the lack of balance sheet insolvency test under the Code as highlighted has immense scope to resolve existing insolvency determination crisis for efficient debtor resolution. As seen in the paper, leading insolvency jurisdiction like the US and UK despite statutorily adopting either of the two tests have judicially developed the simultaneous application of the both the tests. Indeed, the IBBI and the Courts can take reference from the legal position developed in jurisdictions like US and UK to further augment the reforms of Indian insolvency law. The Indian position under the Companies Act, 1956 and 2013 was also gradually accepting the need for having broad determination of inability to pay during windingup. However, the advent of the IBC, having adopted the strict default-based cash flow test, has undermined the development of the jurisprudence on the balance sheet insolvency test. It still remains to be seen if in a particular case the Indian insolvency courts take recourse to Rule 11 NCLT Rules and incorporate the balance sheet insolvency as a stop-gap measure towards malleable resolution. The judicial and regulatory reforms can in absence of legislative amendments facilitate such broad-based reorganisation. Moreover, the reforms have the capacity of improving ease of doing business by empowering corporate debtors a tool against malicious and threating debt recovery, thereby achieving its real purpose. 